Article

\title{
Combination of Autoclave Treatment and NDIR Process Analytics for Quantification of Aluminum Carbide in Powdery Samples
}

\author{
Stefan Niedermayer * (D) and Markus Ellersdorfer
}

Citation: Niedermayer, S.; Ellersdorfer, M. Combination of Autoclave Treatment and NDIR Process Analytics for Quantification of Aluminum Carbide in Powdery Samples. Analytica 2022, 3, 106-119. https://doi.org/10.3390/ analytica3010008

Academic Editor: Marcello Locatelli

Received: 5 January 2022

Accepted: 11 February 2022

Published: 25 February 2022

Publisher's Note: MDPI stays neutral with regard to jurisdictional claims in published maps and institutional affiliations.

Copyright: (C) 2022 by the authors. Licensee MDPI, Basel, Switzerland. This article is an open access article distributed under the terms and conditions of the Creative Commons Attribution (CC BY) license (https:/ / creativecommons.org/licenses/by/ $4.0 /$ )
Chair of Process Technology and Industrial Environmental Protection, Montanuniversität Leoben, 8700 Leoben, Austria; markus.ellersdorfer@unileoben.ac.at

* Correspondence: stefan.niedermayer@unileoben.ac.at

\begin{abstract}
Aluminum Carbide $\left(\mathrm{Al}_{4} \mathrm{C}_{3}\right)$ is a main source of corrosion problems in metal matrix composites as well as refractory products. Hydrolysis to methane happening at room temperature leads to various structural problems. As methods to quantify $\mathrm{Al}_{4} \mathrm{C}_{3}$ are scarce, this paper proposes a method to measure $\mathrm{Al}_{4} \mathrm{C}_{3}$ containing analyte powders in $\mathrm{mg}$ areas by combining a robust autoclave system with non-dispersive infrared (NDIR) process analytics. The method uses only water as reagent, making it easy and safe to handle. The used materials were characterized by thermogravimetric analysis coupled with fourier-transformation infrared detection (TGA-IR), LECO-C analysis, and X-ray diffraction (XRD) before and after autoclave treatment. 90-90.8\% recovery of $100 \mathrm{mg} \mathrm{Al}_{4} \mathrm{C}_{3}$ with small standard deviations $(<1 \%$ at $\mathrm{n}=3)$ in 240,205 , and $165 \mathrm{~min}$ at 60,70 , and $80{ }^{\circ} \mathrm{C}$, respectively, were achieved. XRD analysis showed the total conversion of $\mathrm{Al}_{4} \mathrm{C}_{3}$ to Bayerite $\left(\mathrm{Al}(\mathrm{OH})_{3}\right)$ and Boehmite $(\mathrm{AlO}(\mathrm{OH}))$ at $70{ }^{\circ} \mathrm{C}$. Comparison with shrinking core models showed that the reaction is neither purely reaction nor purely ash diffusion controlled. The findings indicate possibilities for further acceleration of reaction speeds by increasing temperature. The $200 \mathrm{~mL}$ reactor volume of the autoclave enables the analysis of bigger sample sizes at temperatures above $100{ }^{\circ} \mathrm{C}$ by separating reaction and analysis procedure. This provides an extension to gas chromatographic methods for industrial quality control of bulk materials in rougher environments.
\end{abstract}

Keywords: Aluminum Carbide; quantification; autoclave; NDIR; process analytics

\section{Introduction}

Aluminum Carbide $\left(\mathrm{Al}_{4} \mathrm{C}_{3}\right)$ is a carbide of the group of methanogenic carbides. It is formed when materials containing aluminum and carbon are exposed to temperatures above $500{ }^{\circ} \mathrm{C}[1-4]$ according to Equation (1).

$$
4 \mathrm{Al}+3 \mathrm{C} \rightarrow \mathrm{Al}_{4} \mathrm{C}_{3}
$$

These conditions occur during the production or welding of Metal Matrix Composites (MMCs) [5,6]. Therefore, it is often a product of interfacial reactions in the production process of $\mathrm{Si}-\mathrm{Al}-\mathrm{C}$ materials, where the formation of $\mathrm{Al}_{4} \mathrm{C}_{3}$ can also occur according to Equation (2) $[5,7]$.

$$
4 \mathrm{Al}(\mathrm{l})+3 \mathrm{SiC}(\mathrm{s}) \rightarrow \mathrm{Al}_{4} \mathrm{C}_{3}(\mathrm{~s})+3 \mathrm{Si}(\mathrm{s})
$$

$\mathrm{Al}_{4} \mathrm{C}_{3}$ has possible applications in electronic fields [8,9] or as reinforcement of Al-matrix materials [10].

However, it plays a major role in corrosion processes due to its affinity for hydrolysis. This reaction already occurs at room temperature with ambient humidity [7]. Hydrolysis leads to the formation of Aluminum hydroxide $\left(\mathrm{Al}(\mathrm{OH})_{3}\right)$ and methane $\left(\mathrm{CH}_{4}\right)$ according to Equation (3) $[7,11,12]$. 


$$
\mathrm{Al}_{4} \mathrm{C}_{3}+12 \mathrm{H}_{2} \mathrm{O} \rightarrow 4 \mathrm{Al}(\mathrm{OH})_{3}+3 \mathrm{CH}_{4}
$$

The process results in a volume expansion, causing internal stress and fractures in the material $[12,13]$. Therefore, the degradation of $\mathrm{Al}_{4} \mathrm{C}_{3}$ influences the mechanical and thermal properties of a material $[11,14]$.

Many groups working on compound materials are aware of this problem and, therefore, many publications regarding favorable production conditions and avoiding the formation of $\mathrm{Al}_{4} \mathrm{C}_{3}$ can be found [6,15]. Nowadays, there are also artificial intelligence and machine learning based approaches for optimizing production conditions [16].

The formation of $\mathrm{Al}_{4} \mathrm{C}_{3}$ also happens in $\mathrm{MgO}-\mathrm{C}$ bricks containing aluminum ( $\mathrm{Al}$ ) as an antioxidant at temperatures above the melting point of Al. Its hydrolyzation leads to fracturing, changes of shape and disintegration, limiting storage stability [13,17].

However, information on quantification methods for it are scarce [18]. Current analysis techniques mainly include X-ray diffraction (XRD), light microscopy and scanning electron microscopy (SEM). These methods are limited by small sample sizes or high limits of quantification. Therefore, they are commonly used for semi-quantitative analysis, microstructure observations and identification of phase transitions $[7,13,18]$. X-ray photoelectron spectroscopy (XPS) may also give qualitative and quantitative information but is also limited to small sample sizes in addition to being surface sensitive [19].

Methods utilizing methane measurement by gas chromatography (GC) or gas chromatography coupled with mass spectroscopy (GC-MS) were also published. While these methods have low limits of quantification and very high precision, they also require expensive analytical equipment, controlled ambient conditions, and are limited to small sample sizes (0.5-1.5 g). Additionally, all found publications make use of electrolysis, $\mathrm{NaOH}$, or acids for disintegration and converting $\mathrm{Al}_{4} \mathrm{C}_{3}$ to $\mathrm{CH}_{4}$ [18,20-22].

Furthermore, due to necessary operating conditions, these methods are not applicable as at-line analytics in industrial environments due to vibrations or dust.

Recent advances, mainly driven by the area of environmental analytics, led to the development of robust and cheap detection systems for $\mathrm{CH}_{4}$ analytics. The measurement of $\mathrm{CH}_{4}$ is relevant in several fields, ranging from livestock production [23] to measurements of methane emissions in the oil and gas sector $[24,25]$. These systems are mainly based on optical measurement in the infrared spectrum. They enable the usage of new combinations to make quality control as well as $\mathrm{Al}_{4} \mathrm{C}_{3}$ quantification viable in industrial environments.

Therefore, this paper aims to show a simple possibility of quantifying $\mathrm{Al}_{4} \mathrm{C}_{3}$ contents in the mg range with fast, robust, standardized, easy-to-handle, and relatively cheap equipment. This is achieved by combining an autoclave with an NDIR detector calibrated for $\mathrm{CH}_{4}$ measurement. The concepts of previous works [26,27] are adapted and simplified to enable the measurement of powder samples containing $\mathrm{Al}_{4} \mathrm{C}_{3}$. The only additional chemical needed is distilled water, which makes the process favorable regarding working safety. The usage of an autoclave enables sample amounts of up to a few grams of powder sample as stated by Zefferer [26] and Janz [27].

The completeness of the reaction as well as the reproducibility of the device need to be evaluated to get an idea of possible applications. Furthermore, the kinetics of the reaction in the proposed reactor needs to be evaluated to ensure that further optimizations in reaction speed can be achieved at higher temperatures. This would result in shorter analysis times and higher sample throughput by utilizing the autoclave's ability to operate at temperatures above $100{ }^{\circ} \mathrm{C}$.

This indicates that the proposed method, in a modified form, might be an applicable extension to already existing methods for quality control, raw material analysis, and analysis of recycling material. These materials often come in great quantities and the inhomogeneous dispersion of $\mathrm{Al}_{4} \mathrm{C}_{3}$ necessitates the analysis of larger sample amounts. 


\section{Materials and Methods}

\subsection{Sample Material}

The analyzed samples consisted of commercially available Aluminum Carbide $\left(\mathrm{Al}_{4} \mathrm{C}_{3}\right)$ produced by Starck (AB 13560, Lot\# 26113/15). The samples were stored in PP tubes filled with argon and sealed with parafilm. The sealed tubes were placed in a desiccator filled with argon to protect them from unwanted hydrolyzation by ambient humidity.

\subsection{Thermogravimetric Analysis Coupled with Infrared Gas Detection (TGA-IR)}

TGA analysis was performed on a Jupiter STA 449C by Netzsch. The device was equipped with a platinum oven for temperatures up to $1500{ }^{\circ} \mathrm{C}$. The heating curve was linear with a slope of $5{ }^{\circ} \mathrm{C} / \mathrm{min}$ up to $1300^{\circ} \mathrm{C}$. The analyses were performed using $60 \mathrm{~mL} / \mathrm{min}$ dry technical air. Weight constancy of the used crucibles was achieved by annealing at $1400{ }^{\circ} \mathrm{C}$ prior to the TGA measurement. For each measurement, $10-20 \mathrm{mg} \mathrm{Al}_{4} \mathrm{C}_{3}$ powder was weighed in a $20 \mu \mathrm{L} \mathrm{Al}{ }_{2} \mathrm{O}_{3}$ crucible. Buoyancy correction was carried out by subtracting the curve of an empty crucible with identical measurement conditions from the actual sample measurement. The exhaust gas was tempered to $200{ }^{\circ} \mathrm{C}$ and analyzed in a Bruker Tensor II fourier transformation infrared (FT-IR) spectrometer. $\mathrm{CO}_{2}$ was measured at $2360 \mathrm{~cm}^{-1}$, $\mathrm{H}_{2} \mathrm{O}$ at $1500 \mathrm{~cm}^{-1}$, and $\mathrm{CH}_{4}$ at $3013 \mathrm{~cm}^{-1}$.

\subsection{XRD Analysis}

The powder samples were characterized by XRD with a Brucker D8 Advanced with LynxEye Detector with a $\mathrm{Cu}$ tube as X-Ray source and a Ni filter. The divergence slit was set to $0.4^{\circ}$ fix, and the anti-scattering slit to $8 \mathrm{~mm}$. The detector slit setting was $2.5^{\circ}$ and the measurement range was 6 to $70^{\circ}$ with $0.009^{\circ}$ and $0.5 \mathrm{~s}$ per step. The samples were prepared via back loading into a sample ring. Data acquisition and evaluation was conducted using the Bruker DIFFRACplus Basic EVA Software.

\subsection{Total Carbon Analysis}

The analysis of total carbon was conducted with a LECO CS 744. A total of $20-50 \mathrm{mg}$ of $\mathrm{Al}_{4} \mathrm{C}_{3}$ sample were weighed in porcelain crucibles and covered with Lecocel. The sample was then combusted in an oxygen stream above $2000^{\circ} \mathrm{C}$. The reaction gases were analyzed with NDIR detectors.

\subsection{Free Carbon Analysis}

For measuring the free carbon (non- $\mathrm{Al}_{4} \mathrm{C}_{3}$-Carbon), approximately $100 \mathrm{mg}$ of sample were weighed in porcelain crucibles, covered, and combusted in an oxygen stream at $850{ }^{\circ} \mathrm{C}$ for $300 \mathrm{~s}$. The reaction gases were measured using NDIR detectors. This method is similar to DIN 51075-2 for silicon carbide measurement, but instead of a Coulomat, the C analyzer LECO RC 612 was used.

\subsection{SEM Analysis}

SEM analyses were conducted with a JEOL JSM-7900F field emission gun scanning electron microscope at $10 \mathrm{kV}$ acceleration voltage, a probe current of $2.00 \mathrm{nA}$, and an $11 \mathrm{~mm}$ working distance. The images were acquired using Aztec software.

\subsection{Particle Size Measurement}

The measurement was conducted with a Helos device (R3) equipped with a Rodos/L unit for dry dispersion and a Vibri dosing unit. Approximately $20 \mathrm{~g}$ samples were fed into the dispersing unit at a flow rate of $30 \%$ with a gap width of $15 \mathrm{~mm}$. The dispersion unit was set to 3 bar with a negative pressure of 41 mbar. The starting point was set to $\mathrm{C}_{\mathrm{opt}}$ (optical concentration) $\geq 1 \%$ and the end point to $C_{\text {opt }} \leq 1 \%$ for $5 \mathrm{~s}$. Data acquisition and calculations were done with PAQXOS 3.0.2 software. 


\subsection{Gas Analytics}

The autoclave system consisted of a $200 \mathrm{~mL}$ reaction vessel coated with PTFE on the inside. The device was able to measure pressure and temperature. The lid of the autoclave was equipped with needle valves for liquid sampling, gas insertion and gas sampling. The system was equipped with an adjustable bypass from the inlet to the outlet valve to enable baseline correction of the sensors as well as slower pressure relieve. Heating and stirring was performed by using a magnetic stirring plate connected to a temperature controller. The gas measuring system consisted of a Bronckhorst thermal mass flow meter for measuring the $\mathrm{N}_{2}$ (5.0) stream. A constant dry gas stream was ensured by using a cooling pump. For methane detection, a non-dispersive infrared (NDIR) analyzer, measuring ppmV $\mathrm{CH}_{4}$, was used. An additional flowmeter acting as a pressure release valve was installed (Scheme 1). The measurements were conducted by preheating the vessel and the distilled water. Around $100 \mathrm{mg}$ of $\mathrm{Al}_{4} \mathrm{C}_{3}$ were weighed and inserted in the PTFE liner. The PTFE liner was put in the reaction vessel and all valves were opened. After flushing the autoclave with $\mathrm{N}_{2}$, all valves were closed and the liner was heated up. The $\mathrm{N}_{2}$ flowrate was adjusted to approximately $1 \mathrm{Ln} / \mathrm{min}$ (normal liter, $T=273.15 \mathrm{~K}, p=101,325 \mathrm{~Pa}$ ). When the detector showed a stable zero signal and the autoclave had reached trial temperature, the preheated water was injected via the liquid input valve, which was closed afterwards. The gas input and output valves were opened, the bypass was closed, and the data acquisition program was started. The stirring was activated at $1000 \mathrm{rpm}$ and the reaction was continuously monitored in one second intervals until the methane content in the $\mathrm{N}_{2}$ stream dropped below 10 ppmV. Data acquisition was done via LabView.

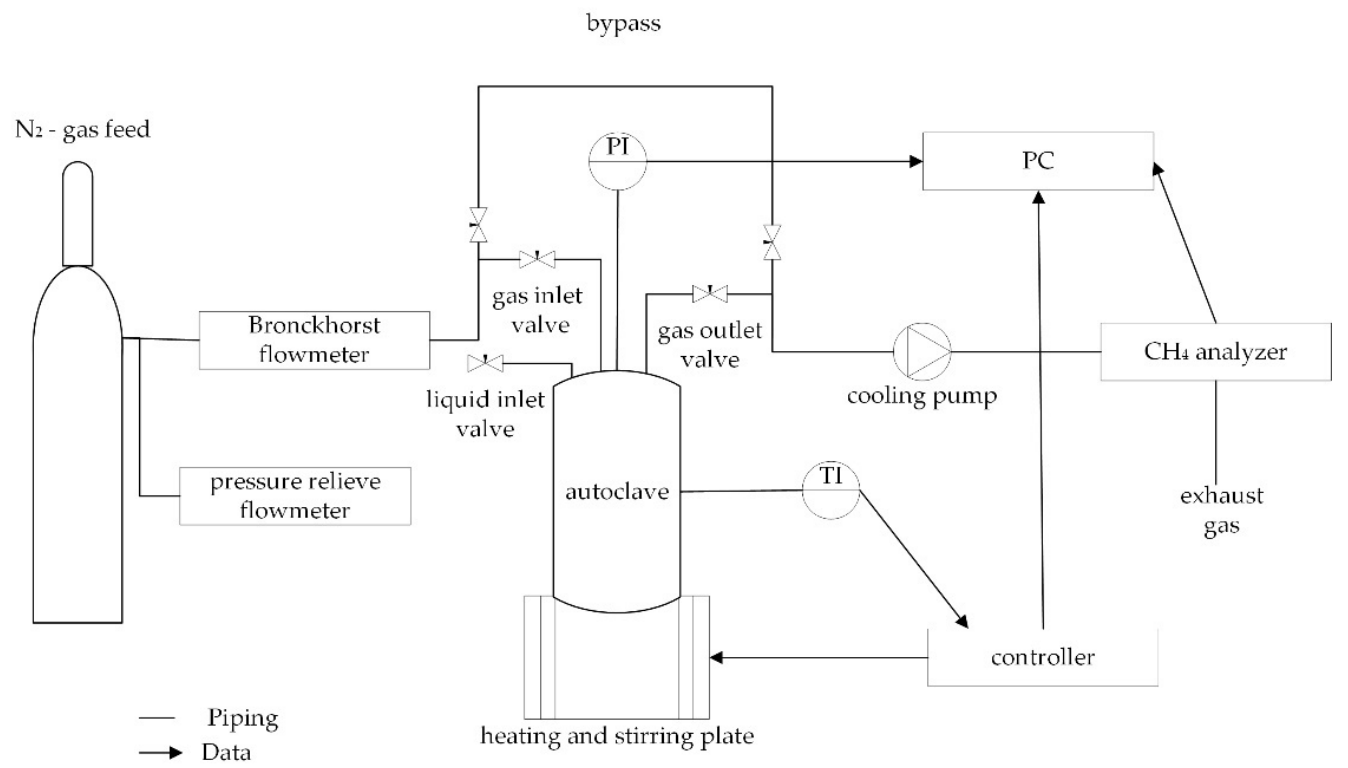

Scheme 1. Flowchart of the constructed analytical apparatus.

Calculation of the methane volume produced by the sample was conducted according to Equation (4).

$$
V\left(\mathrm{CH}_{4}\right)_{\mathrm{x}}=\left(t_{\mathrm{x}}-t_{\mathrm{x}-1}\right) * \frac{\dot{V}_{\mathrm{n}\left(\mathrm{N}_{2}\right)_{\mathrm{x}}}}{60 \frac{\mathrm{s}}{\min } * 10^{3} \frac{\mathrm{L}_{\mathrm{n}}}{\mathrm{m}^{3} \mathrm{n}}} * \frac{w\left(\mathrm{CH}_{4}\right)_{\mathrm{x}}}{10^{6} \mathrm{ppmV}}
$$

- $V\left(\mathrm{CH}_{4}\right)_{\mathrm{x}} \ldots$ Volume $\mathrm{CH}_{4}$ at point $\mathrm{x}$ (normal cubic meter $=\mathrm{m}^{3}{ }_{\mathrm{n}} ; \mathrm{T}=273.15 \mathrm{~K}$, $p=101,325 \mathrm{~Pa})$

- $\quad t_{\mathrm{x}} \ldots$ time at point $\mathrm{x}(\mathrm{s})$

- $\dot{V}_{\mathrm{n}\left(\mathrm{N}_{2}\right)_{\mathrm{x}}} \ldots$ normal volumetric flow rate of $\mathrm{N}_{2}$ at point $\mathrm{x}\left(\mathrm{L}_{\mathrm{n}} / \mathrm{min}\right)$

- $w\left(\mathrm{CH}_{4}\right) \ldots$ measured concentration of $\mathrm{CH}_{4}$ at point $\mathrm{x}(\mathrm{ppmV})$ 
As the flowmeter detects the volume flow rate of $\mathrm{N}_{2}$ in normal liters per minute and the measurements were conducted at ambient conditions, the ideal gas equation was used to calculate the amount of $\mathrm{CH}_{4}$ (Equation (5)).

$$
n\left(\mathrm{CH}_{4}\right)_{\mathbf{x}}=\frac{p * V\left(\mathrm{CH}_{4}\right)_{\mathbf{x}}}{R * T}
$$

- $n\left(\mathrm{CH}_{4}\right)_{\mathrm{x}} \ldots$ amount of substance of $\mathrm{CH}_{4}$ at point $\mathrm{n}(\mathrm{mol})$

- $\quad p \ldots$ pressure $(101,325 \mathrm{~Pa})$

- $\quad$ R ... universal gas constant $\left(8.314 \mathrm{~J} / \mathrm{mol}^{*} \mathrm{~K}\right)$

- $\quad$. . . Temperature $(273.15 \mathrm{~K})$

The calculated amount of $\mathrm{CH}_{4}$ was used to determine the amount of $\mathrm{Al}_{4} \mathrm{C}_{3}$ needed for its production according to Equation (6).

$$
m\left(\mathrm{Al}_{4} \mathrm{C}_{3}\right)=\sum_{\mathrm{x}=1}^{\text {end }} n\left(\mathrm{CH}_{4}\right)_{\mathrm{x}} * \mathrm{RR} * M\left(\mathrm{Al}_{4} \mathrm{C}_{3}\right)
$$

- $\quad m\left(\mathrm{Al}_{4} \mathrm{C}_{3}\right) \ldots$ mass of $\mathrm{Al}_{4} \mathrm{C}_{3}$ measured $(\mathrm{g})$

- $\quad \mathrm{RR} \ldots$ reaction ratio $(1 / 3)$

- $M\left(\mathrm{Al}_{4} \mathrm{C}_{3}\right) \ldots$ molar mass $\mathrm{Al}_{4} \mathrm{C}_{3}(143.96 \mathrm{~g} / \mathrm{mol})$

Recovery was calculated as the ratio of $\mathrm{Al}_{4} \mathrm{C}_{3}$ divided by the amount of $\mathrm{Al}_{4} \mathrm{C}_{3}$ weighed in Equation (7).

$$
\operatorname{Recovery}(\%)=\frac{m\left(\mathrm{Al}_{4} \mathrm{C}_{3}\right)}{m_{0}\left(\mathrm{Al}_{4} \mathrm{C}_{3}\right)} * 100
$$

- $m_{0}\left(\mathrm{Al}_{4} \mathrm{C}_{3}\right) \ldots$ mass of $\mathrm{Al}_{4} \mathrm{C}_{3}$ weighed in $(\mathrm{g})$

The conversion was calculated analogically, summing up the measured masses until the respective point of interest (y) and dividing it by the total measured mass according to Equation (8).

$$
\text { Conversion }(\%)=\frac{\sum_{\mathrm{x}=1}^{\mathrm{y}} n\left(\mathrm{CH}_{4}\right)_{\mathrm{x}} * \mathrm{RR} * M\left(\mathrm{Al}_{4} \mathrm{C}_{3}\right)}{m\left(\mathrm{Al}_{4} \mathrm{C}_{3}\right)} * 100
$$

\subsection{Preparation of Treated Samples}

For TGA-IR, XRD, SEM, and carbon analysis after treatment, $2 \mathrm{~g}$ of $\mathrm{Al}_{4} \mathrm{C}_{3}$ powder were weighed in. After treatment with $100 \mathrm{~mL}$ distilled water at $70{ }^{\circ} \mathrm{C}$ for $4 \mathrm{~h}$ in the constantly $\mathrm{N}_{2}$-flushed autoclave, the solution was evaporated at $105^{\circ} \mathrm{C}$ for $12 \mathrm{~h}$

\section{Results and Discussion}

\subsection{Principle of the Measurement}

The measurement is based on the $\mathrm{CH}_{4}$ concentration in the $\mathrm{N}_{2}$ stream. Figure 1 shows the progress of the average measured methane concentration in the $\mathrm{N}_{2}$ stream versus the time. The temperatures of 60 to $80{ }^{\circ} \mathrm{C}$ were chosen based on pretrials showing a much slower conversion from room temperature to $40^{\circ} \mathrm{C}$. This was also supported by the findings of Nýblová et al. [12], indicating the time needed for total hydrolysis in water at room temperature to be in the area of days. These temperatures would result in trial times without any practical applicability.

The graphs show that the measured maximum concentrations decreased with lower temperatures from $1730 \mathrm{ppm}$ at $80^{\circ} \mathrm{C}$ to $615 \mathrm{ppm}$ at $60^{\circ} \mathrm{C}$. The time needed to reach the maximum concentration increased from $4 \mathrm{~min}$ at $80{ }^{\circ} \mathrm{C}$ to $23 \mathrm{~min}$ at $60{ }^{\circ} \mathrm{C}$. All curves showed a rapid initial increase. The 70 and $80^{\circ} \mathrm{C}$ curves reached a peak before a plateau followed by decrease. The $60{ }^{\circ} \mathrm{C}$ showed a plateau before decreasing. The curves crossed at approximately $40 \mathrm{~min}$. From then onward, all curves showed a steady decrease to below $10 \mathrm{ppm}$. The methane production showed an initial lag phase with no $\mathrm{CH}_{4}$ production, followed by a fast reaction step, making it comparable to the reaction of mechanically 
activated metallic $\mathrm{Al}$ in hot water, producing $\mathrm{H}_{2}$ [28]. The initial lag phase also showed a temperature dependency, gradually decreasing from 60 to $80{ }^{\circ} \mathrm{C}$. Therefore, the assumption that a further increase in temperature leads to even shorter times until complete conversion can be made. This would result in even shorter analysis times.

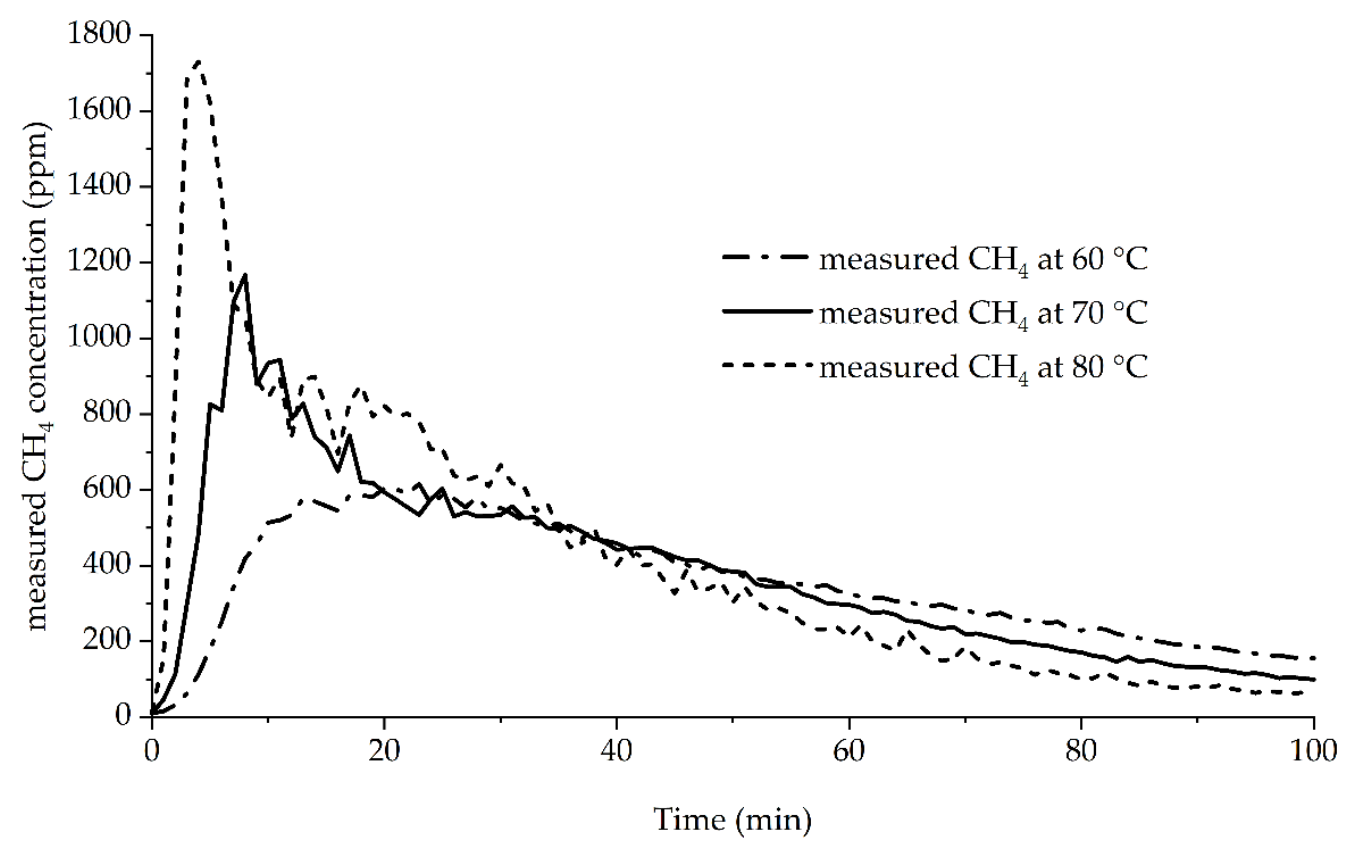

Figure 1. Mean $\mathrm{CH}_{4}$ concentrations in the $\mathrm{N}_{2}$ analysis stream $(n=3)$ in one-minute intervals for trials at the corresponding temperature from 0 to $100 \mathrm{~min}$. The curves showed a steady decline to below $10 \mathrm{ppm}$ after $100 \mathrm{~min}$, and therefore, they are not shown.

The measured methane concentrations from each trial were used to calculate the recovery of $\mathrm{Al}_{4} \mathrm{C}_{3}$ according to Equations (4)-(7), shown in Figure 2.

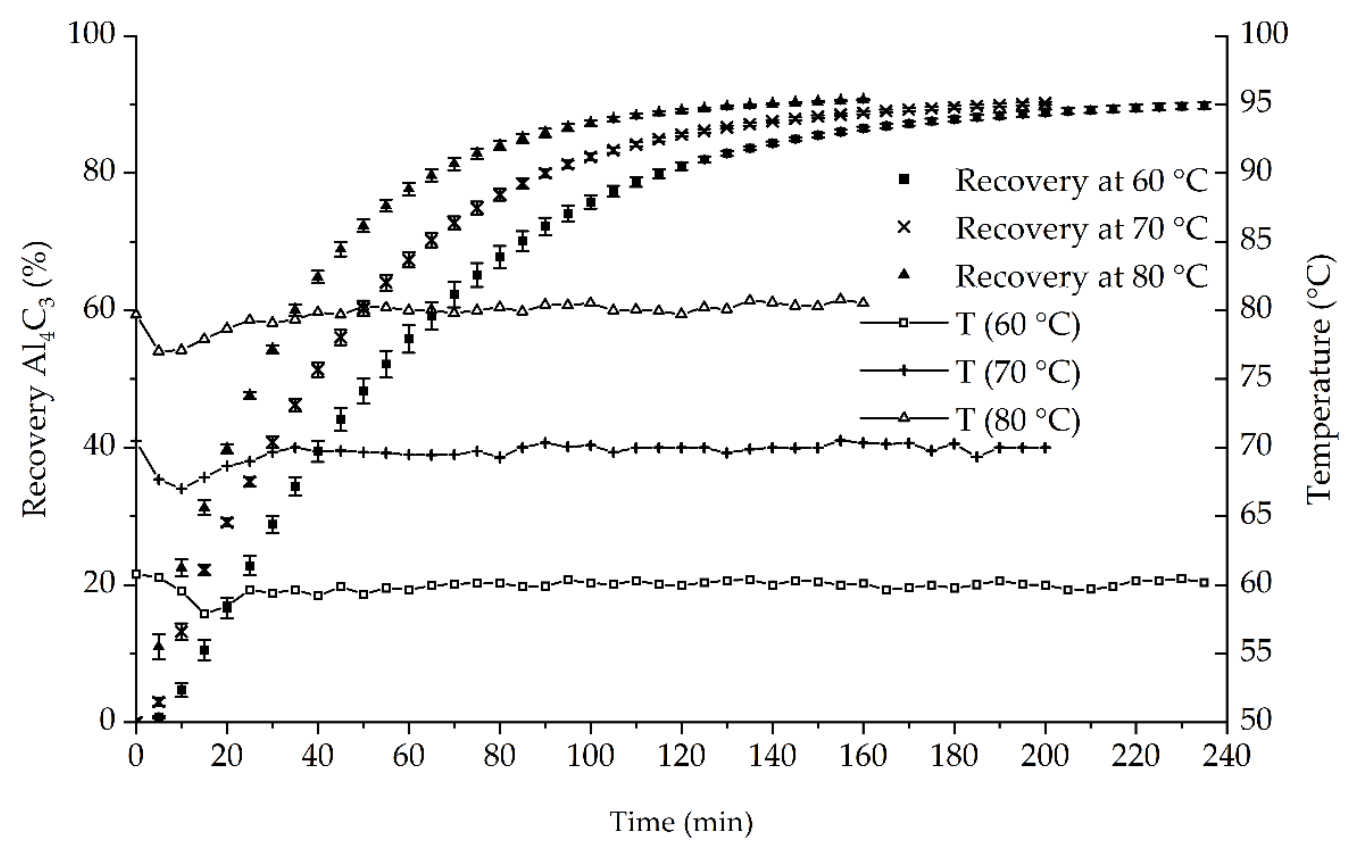

Figure 2. Average $\mathrm{Al}_{4} \mathrm{C}_{3}$ recovery at 60,70 , and $80{ }^{\circ} \mathrm{C}$ based on measured methane indicating the progress of the reaction with error bars $(n=3)$. Each trial was conducted with a sample weight of around $100 \mathrm{mg} \mathrm{Al}_{4} \mathrm{C}_{3}$. Temperature curves are also averages of three trials. 


\subsection{Recovery and Repeatability}

Analytical methods for quantification need to be able to produce repeatable results. Therefore, the next chapter will cover this topic.

Figure 2 shows the temperature dependency of the recovery and the temperature during the trials. Both are plotted in 5-min steps. All markers are the averages of triplicates. Additionally, error indicators are shown for the recovery.

The temperature for each trial was kept at $+/-3{ }^{\circ} \mathrm{C}$ around the nominal value. After the initial settling phase during the first $20-30 \mathrm{~min}$ of each trial, the temperature remained constant.

The recovery is used as an indicator for the reaction velocity. Recovery curves show that the time of the lag phase of the reaction decreased with higher temperatures. The $\mathrm{Al}_{4} \mathrm{C}_{3}$ recovery also showed that the reaction speed positively correlates with increased temperature. The times needed for the $\mathrm{CH}_{4}$ detector to signal the end of the measurement $\left(<10 \mathrm{ppm}\right.$ ) decreased from $240-245 \mathrm{~min}$ at $60^{\circ} \mathrm{C}$ to $160-175 \mathrm{~min}$ at $80^{\circ} \mathrm{C}$ (Table 1$)$.

Table 1. Average time until completion ( $<10 \mathrm{ppm} \mathrm{CH}_{4}$ measured) and calculated recovery after completed trials ( \pm single standard deviation) $(\mathrm{n}=3)$ at 60,70 , and $80^{\circ} \mathrm{C}$.

\begin{tabular}{ccc}
\hline $\begin{array}{c}\text { Temperature } \\
\left({ }^{\circ} \mathbf{C}\right)\end{array}$ & $\begin{array}{c}\text { Average Time until the End of } \\
\text { Analysis }\left(<\mathbf{1 0} \mathbf{~ p p m ~} \mathbf{C H}_{\mathbf{4}}\right) \mathbf{( m i n )}\end{array}$ & $\begin{array}{c}\text { Average Recovery } \\
(\mathbf{\%})\end{array}$ \\
\hline 60 & $241 \pm 2$ & $90.0 \pm 0.5$ \\
70 & $205 \pm 3$ & $90.3 \pm 0.3$ \\
80 & $168 \pm 8$ & $90.8 \pm 0.2$ \\
\hline
\end{tabular}

The average recoveries at the end point are shown in Table 1 and ranged from $90 \%$ at $60{ }^{\circ} \mathrm{C}$ to $90.8 \%$ at $80^{\circ} \mathrm{C}$. The standard deviations below $1 \%$ indicate the method's precision. For this study, this is equal to standard deviations of approximately $1 \mathrm{mg} \mathrm{Al}_{4} \mathrm{C}_{3}$, making it comparable to the method proposed by Yan et al. [18]. However, this method is less precise than GC methods, achieving results in the $\mu \mathrm{g}$ area $[20,22]$.

The produced gas is injected in the $\mathrm{N}_{2}$ stream after the flowmeter. Therefore, the total volume led to the detector is higher than the measured volume. This leads to lower recovery and higher standard deviations. The concentrations of $\mathrm{CH}_{4}$ in the $\mathrm{N}_{2}$ stream were below $1 \%(v / v)$ and thereby led to a decrease of $<1 \%$. These deviations were neglected in the present study. Injecting the produced gas before measuring the volume flow is difficult as changes in heat capacities caused by fluctuating gas composition would influence the measurement.

As the average recoveries were nearly equal and small standard deviations were achieved for all temperatures, the method seems to be able to repeatably quantify $\mathrm{Al}_{4} \mathrm{C}_{3}$. Furthermore, the maximum conversion seems to be independent from temperature.

The selectivity and specificity of the method are ensured by the usage of the NDIR detector for $\mathrm{CH}_{4}$ measurement.

\subsection{Morphology of the Particles}

The SEM pictures (Figure 3) showed mostly polygonal particles before and cylindrical particles after the treatment. The untreated samples (Figure 3a,b) showed smooth surfaces as well as sharp edges. While the treatment $\left(70{ }^{\circ} \mathrm{C}, 4 \mathrm{~h}\right.$ in water $)$ did not dissolve the particles (Figure 3c,d), the surfaces underwent changes, resulting in a cotton-like appearance. Another noticeable difference is that the surfaces of the untreated sample (Figure $3 b$ ) have no visible cracks or fracturing, whereas the surfaces of the treated samples (Figure $3 \mathrm{~d}$ ) have visible cracks. The absence of cracks in the cotton-like particle in Figure $3 \mathrm{c} \mathrm{might}$ be explained by it being metallic $\mathrm{Al}$, indicated by LECO-C analysis deviating from theoretical stoichiometry. This led to different hydrolysis behavior, resulting in differences in appearance. This hypothesis requires further research for confirmation. 


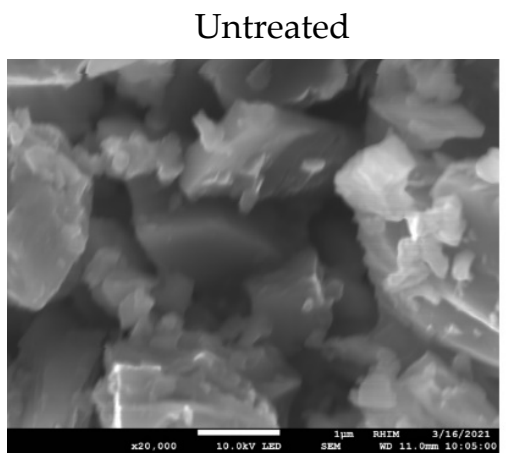

(a)

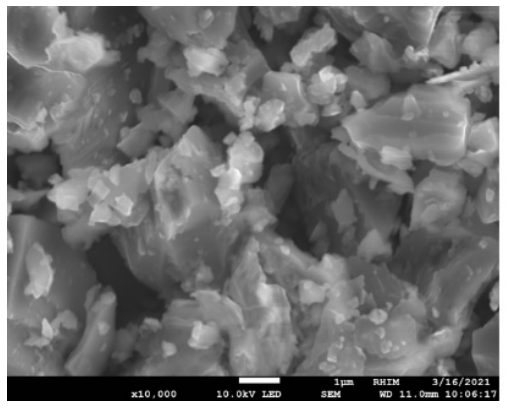

(b)
Treated

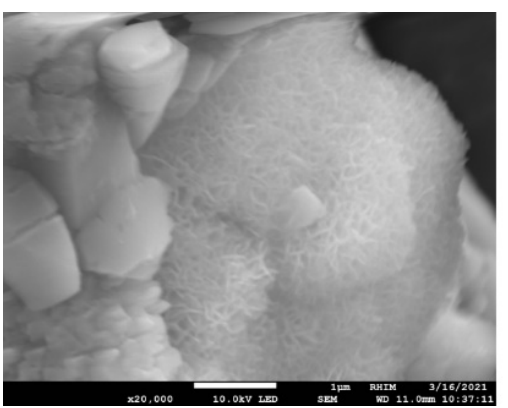

(c)

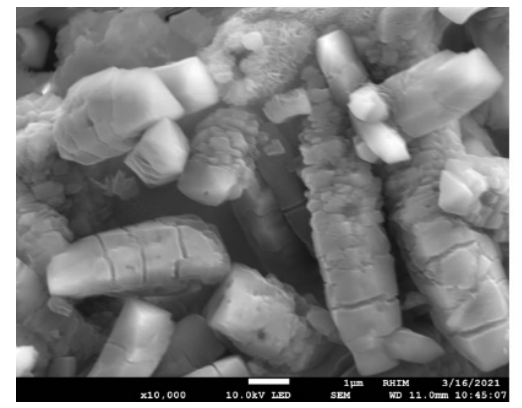

(d)

Figure 3. $\mathrm{SEM}$ pictures of the untreated $(\mathbf{a}, \mathbf{b}) \mathrm{Al}_{4} \mathrm{C}_{3}$ powders and the powder samples after autoclave treatment $\left(70{ }^{\circ} \mathrm{C}, 4 \mathrm{~h}\right)(\mathbf{c}, \mathbf{d})$. The white bar at the bottom center of each figure indicates $1 \mu \mathrm{m}$. (Magnification $(\mathbf{a}, \mathbf{c})$ : 20,000; magnification $(\mathbf{b}, \mathbf{d})$ : 10,000). SEM parameters: $10.0 \mathrm{kV}$ LED, WD $11.0 \mathrm{~mm}$.

The morphological changes can be attributed to the formation of Bayerite $\left(\mathrm{Al}(\mathrm{OH})_{3}\right)$ and Boehmite $(\mathrm{AlO}(\mathrm{OH}))$. This was confirmed by XRD and TGA-IR, and is in accordance with Nýblová et al. [12]. Their study found that $\mathrm{Al}_{4} \mathrm{C}_{3}$ samples mainly consisted of $\mathrm{Al}(\mathrm{OH})_{3}$ with small fractions of $\gamma-\mathrm{AlO}(\mathrm{OH})$ after hydrolyzing it in water for 34 days.

\subsection{Completion of the Reaction}

LECO-C analysis of the untreated sample resulted in total carbon concentrations of $24.1 \%(w / w)(\mathrm{n}=1)$. The determination of organic carbon at lower temperatures resulted in $0.9 \%(w / w)(\mathrm{n}=1)$. This leads to a concentration of carbon from $\mathrm{Al}_{4} \mathrm{C}_{3}$ of $23.2 \%(w / w)$. As the theoretical concentration of carbon in $\mathrm{Al}_{4} \mathrm{C}_{3}$ is $25 \%(w / w)$, there is a deviation leading to lower maximum possible recoveries of $92.8 \%$.

The treated samples resulted in $0.6 \%(w / w)(\mathrm{n}=1)$ total carbon and $0.4 \%(w / w)(\mathrm{n}=1)$ organic carbon. This shows that there is a small amount of carbon left in the sample, which mainly originates from organic carbon.

XRD analysis of the untreated sample (Figure 4) showed a Graphite fraction (26.5 2-Theta) in addition to the diffraction pattern of $\mathrm{Al}_{4} \mathrm{C}_{3}$. As amorphous phases were present, the graphs were baseline corrected to lower noise and obtain more accurate results. The sample treated for $4 \mathrm{~h}$ at $70{ }^{\circ} \mathrm{C}$ in water (Figure 5) showed that the $\mathrm{Al}_{4} \mathrm{C}_{3}$ had mainly changed to $\mathrm{Al}(\mathrm{OH})_{3}$, but also a Boehmite $\mathrm{AlO}(\mathrm{OH})$ fraction had formed. The XRD pattern of the treated sample does not show residual $\mathrm{Al}_{4} \mathrm{C}_{3}$. This indicates that the concentration of $\mathrm{Al}_{4} \mathrm{C}_{3}$ in the powder reached a level below the detection limit of XRD, at approximately $2 \%(w / w)$. The hydrolysis at elevated temperatures led to an increase in amorphous fraction. The graphite fraction (26.5 2-Theta) was still present as it remained unchanged during the treatment. The marked 2-Theta angles are attached in the Supplementary data file. 


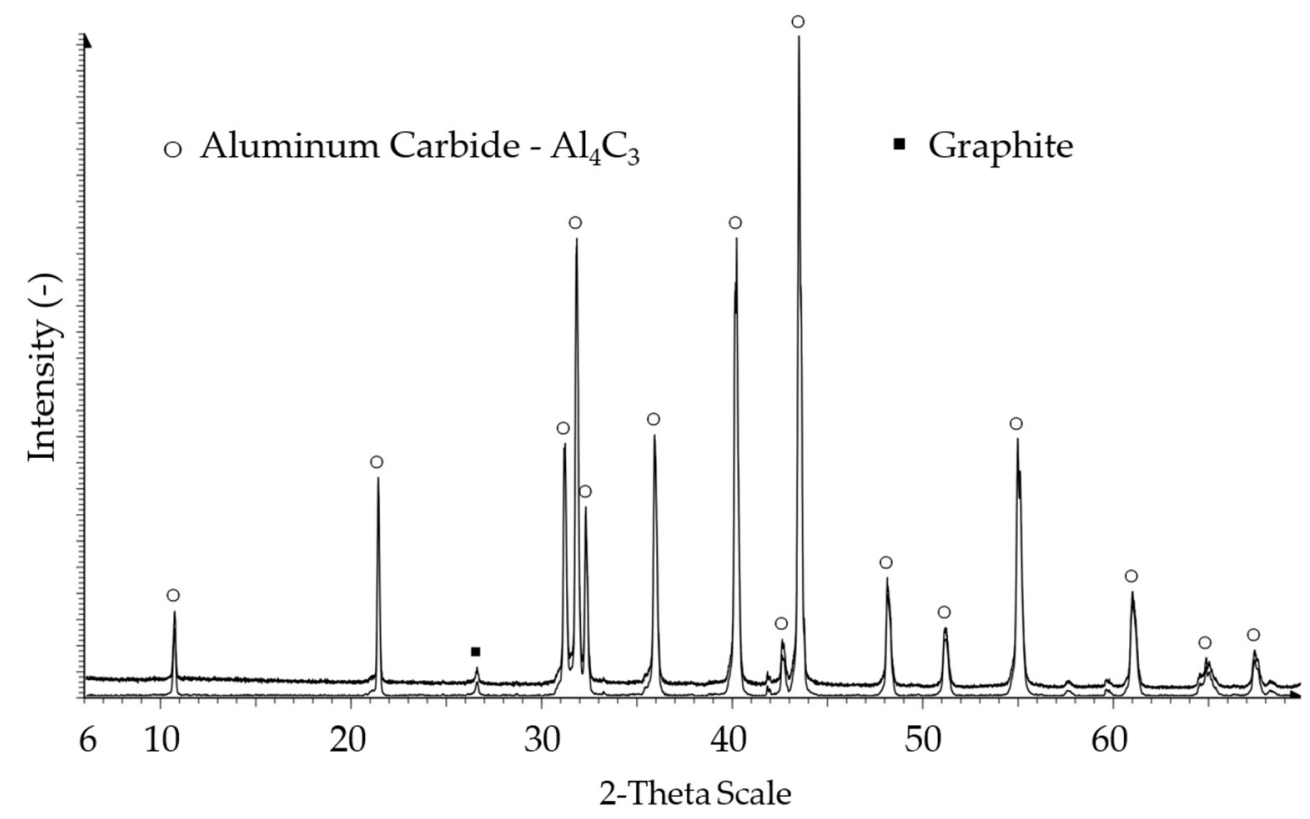

Figure 4. $\mathrm{XRD}$ analysis of the untreated $\mathrm{Al}_{4} \mathrm{C}_{3}$ powder (original and baseline-corrected graph).

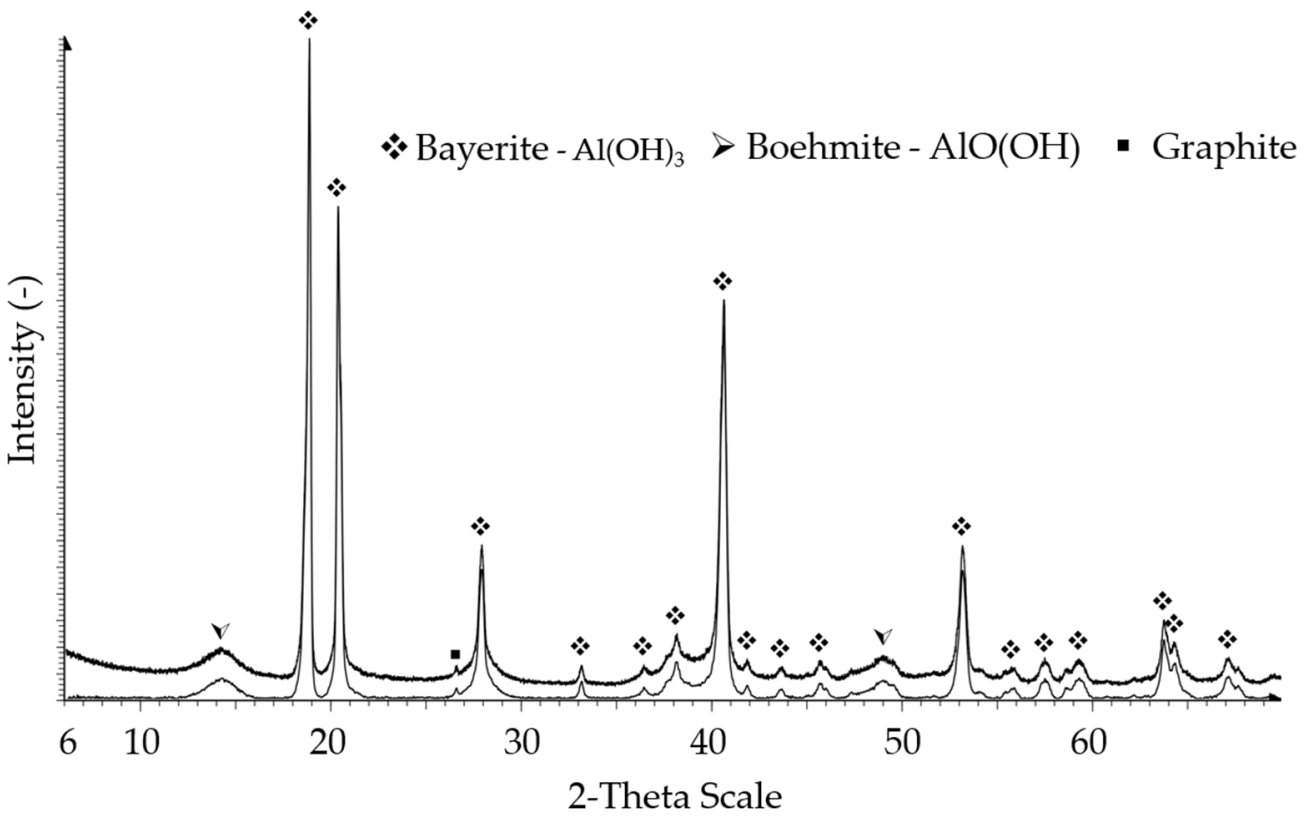

Figure 5. XRD analysis of the $\mathrm{Al}_{4} \mathrm{C}_{3}$ powder after exposure to water for $4 \mathrm{~h}$ at $70{ }^{\circ} \mathrm{C}$ (original and baseline-corrected graph).

In this study, no distinction between effects of autoclave treatment and drying can be made for treated samples. As the effects were caused by distilled water at similar temperatures and recovery of $\mathrm{Al}_{4} \mathrm{C}_{3}$ showed nearly complete conversion according to gas analytics, this was deemed neglectable.

TGA analysis of the untreated sample (Figure 6) showed an initial mass reduction of $1.57 \%(\mathrm{~m} / \mathrm{m})$ at $364{ }^{\circ} \mathrm{C}$. This was probably caused by contact with humidity during the sample preparation, leading to methane formation peaking at $135^{\circ} \mathrm{C}$ and a decrease in mass at $100-150{ }^{\circ} \mathrm{C}$. In the area of $600-800{ }^{\circ} \mathrm{C}$, an increase in $\mathrm{CO}_{2}$ concentration occurred. In this temperature area, the free carbon was analyzed via LECO-C, indicating the oxidation of organic carbon. The increase in mass above $800{ }^{\circ} \mathrm{C}$ to nearly $120 \%$ indicates the start of $\mathrm{Al}_{4} \mathrm{C}_{3}$ oxidation to $\mathrm{Al}_{2} \mathrm{O}_{3}$. This correlates with IR analysis, showing an increase in 
the $\mathrm{CO}_{2}$ concentration. Above $1200{ }^{\circ} \mathrm{C}$, a second increase in mass occurs together with $\mathrm{CO}_{2}$ formation.

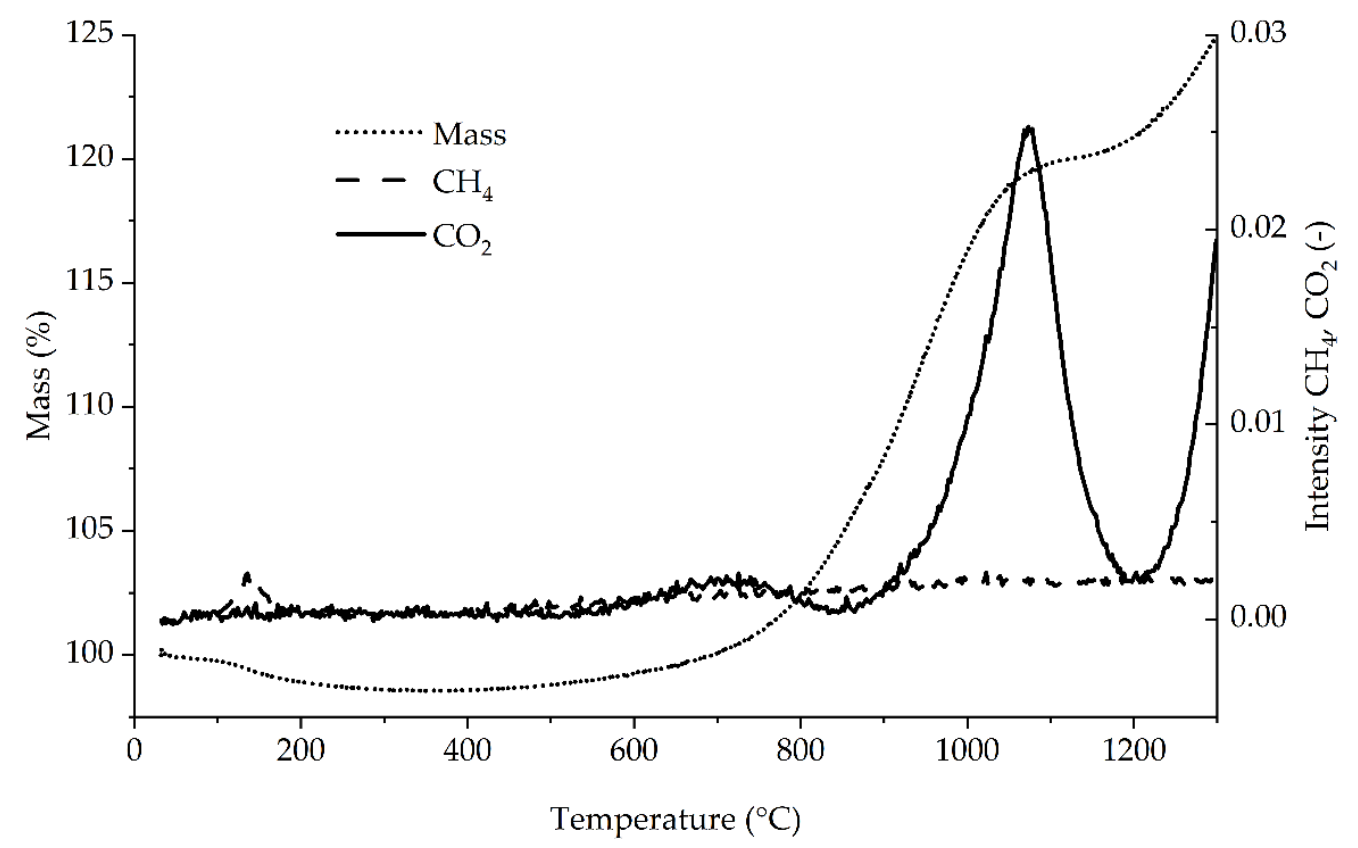

Figure 6. TGA-IR analysis of the untreated $\mathrm{Al}_{4} \mathrm{C}_{3}$ powder sample in air. Starting at $30{ }^{\circ} \mathrm{C}$ with a temperature ramp of $5{ }^{\circ} \mathrm{C} / \mathrm{min}$.

The treated sample (Figure 7) initially showed a slight decrease in mass combined with $\mathrm{CO}_{2}$ formation up to $200{ }^{\circ} \mathrm{C}$. Slightly above $200{ }^{\circ} \mathrm{C}$, there was a sharp decrease in mass to $78 \%$ at $273{ }^{\circ} \mathrm{C}$, and vapor was detected. This indicates the release of crystal water. From $273{ }^{\circ} \mathrm{C}$ to slightly below $520{ }^{\circ} \mathrm{C}$, the mass decrease slowed down until the mass reached approximately $63 \%$. The $\mathrm{CO}_{2}$ formation in this stage indicates oxidation of organic carbon. The double peak shape could not be explained during this study. The $\mathrm{CO}_{2}$ concentration suddenly decreased at $520^{\circ} \mathrm{C}$, correlating with an even slower decrease in mass above $520^{\circ} \mathrm{C}$. The mass decreased further to about $60 \%$ at $1300{ }^{\circ} \mathrm{C}$. IR analysis showed a steady increase in $\mathrm{CO}_{2}$ concentration after the drop at $520^{\circ} \mathrm{C}$. The TGA curves were in accordance with the data of Koga and Yamada [29], who analyzed synthetic Bayerite under vacuum.

Possible explanations for the $\mathrm{CO}_{2}$ curve could be that the oxidation of free carbon starts at lower temperatures and lasts longer, as seen by the increasing $\mathrm{CO}_{2}$ concentration at higher temperatures or the formation of unknown, carbon-containing fractions during the reaction similar to the behavior of $\mathrm{MgO}-\mathrm{C}$ bricks [13]. This would explain the slightly lower recovery as well. Additional research regarding the formed compounds is necessary. This might be conducted by phase identification, such as XRD, or surface identification, such as XPS, with special sample pretreatment.

\subsection{Kinetics and Modelling}

Understanding the kinetics of a reaction is an important step in deciding factors for improvements. Therefore, the next section will try to give a basic concept of the reaction kinetics of the researched reaction.

As the particles remain undissolved, it can be assumed that the reaction happens from the outside to the inside, leading to a core-shell structure. Therefore, the modelling approach of basic shrinking core models (SCM) with reaction or ash diffusion control was used [30]. 


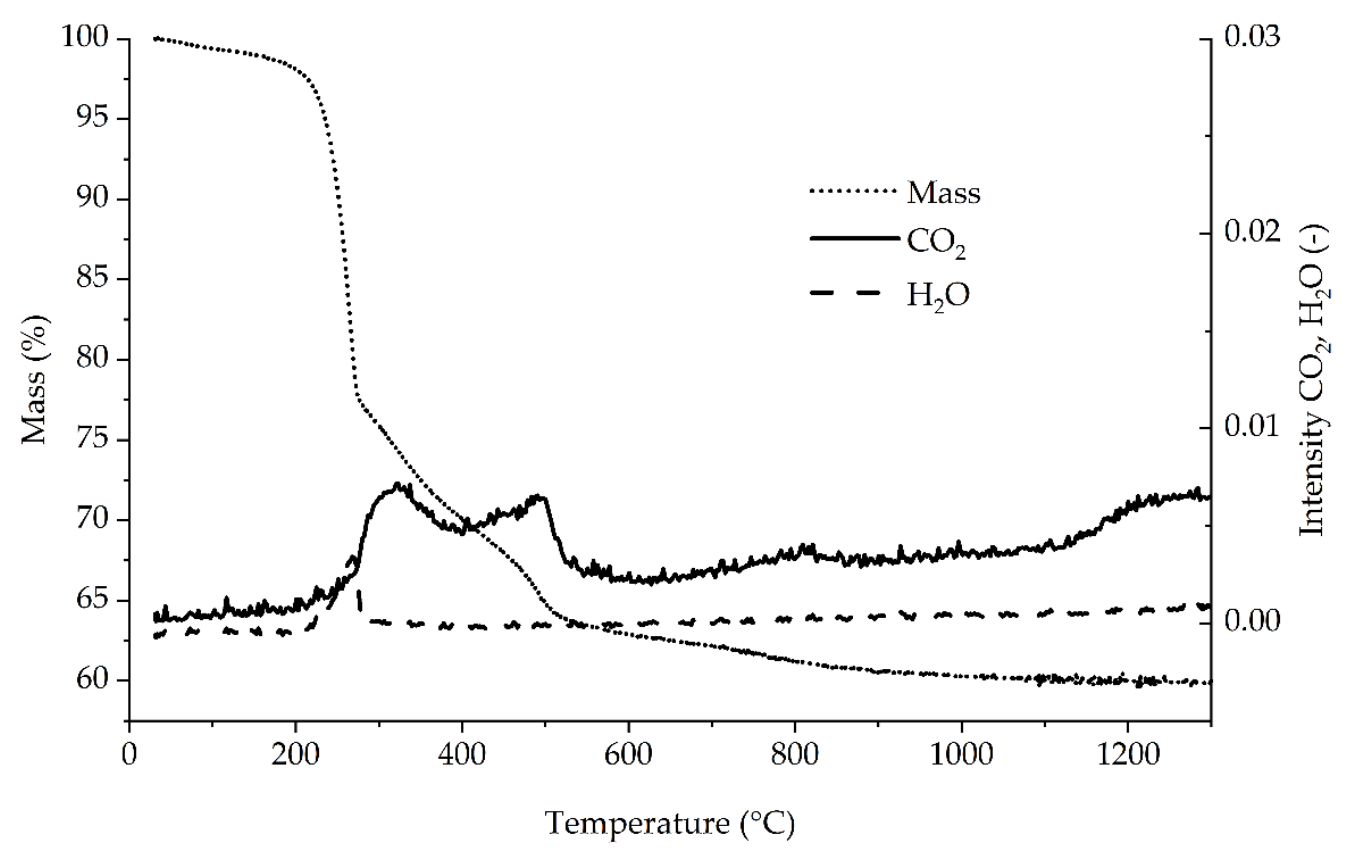

Figure 7. TGA-IR analysis of the treated $\mathrm{Al}_{4} \mathrm{C}_{3}$ powder sample $\left(4 \mathrm{~h}\right.$ at $\left.70{ }^{\circ} \mathrm{C}\right)$ in air. Starting at $30{ }^{\circ} \mathrm{C}$ with a temperature ramp of $5{ }^{\circ} \mathrm{C} / \mathrm{min}$.

Figure 8 shows the model curve of a shrinking core model with either reaction or ash diffusion as the controlling steps and the curves of the trials conducted at $80^{\circ} \mathrm{C}$. The curves of these trials were chosen because they showed nearly no initial lag phase.

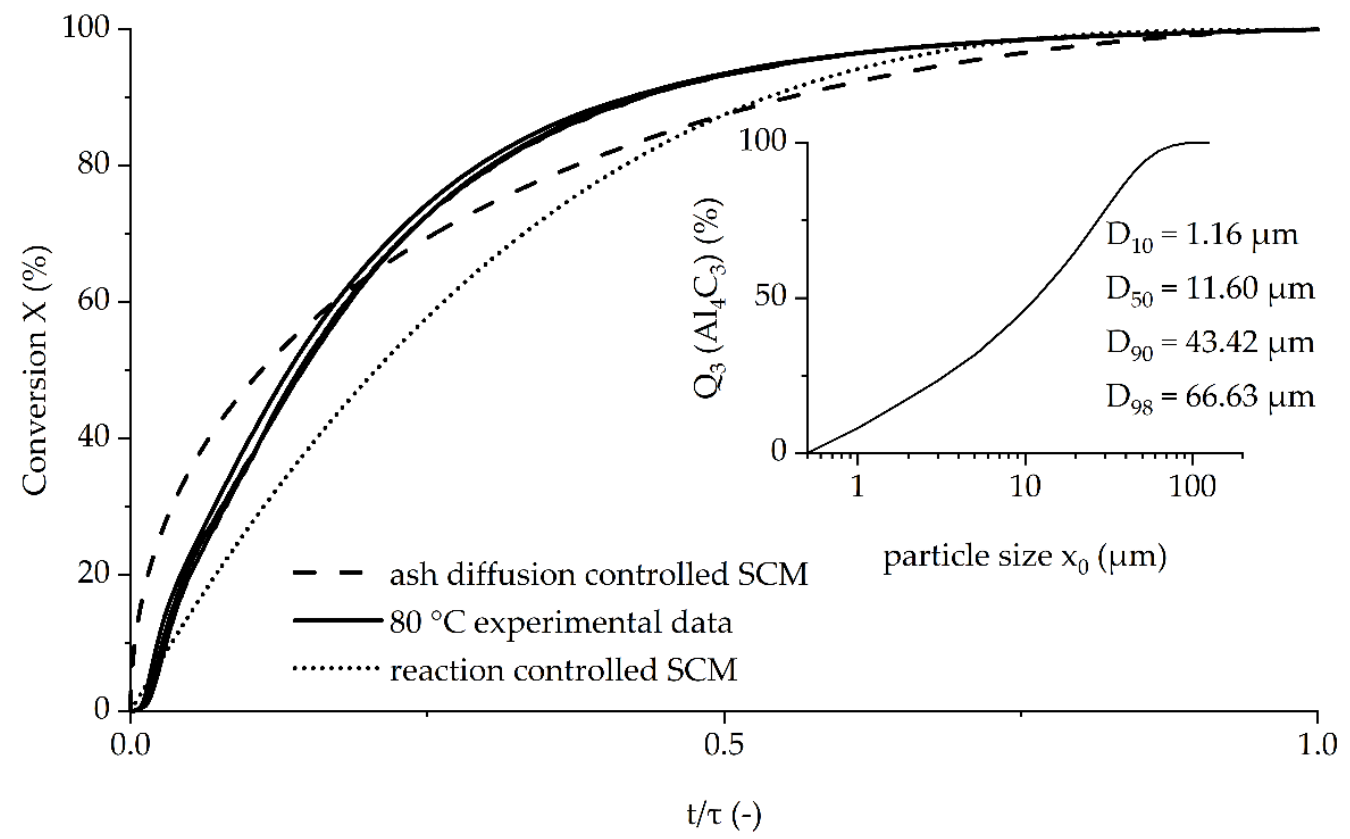

Figure 8. Comparison of a shrinking core model with either ash diffusion control (dashed line) or reaction control (dotted line) with the experimental data obtained at $80{ }^{\circ} \mathrm{C}$. $\tau$ represents the time until complete conversion. The inlet depicts the particle size distribution of the $\mathrm{Al}_{4} \mathrm{C}_{3}$ powder with a logarithmic x-axis.

Since the exact initial concentration, and thereby the maximum conversion and conversion time, were unknown, simplifying assumptions were made:

- At the end of each trial ( $<10 \mathrm{ppm} \mathrm{CH}_{4}$ measurement signal) a conversion of $100 \%$ was reached. 
- The time for complete conversion $\tau$ was assumed to be the total reaction time for the corresponding trial.

The figure shows that the trials are reproducible. The experimental data was between the initially faster ash diffusion-controlled model (Equation (9), dashed line) and the initially slower reaction-controlled model (Equation (10), dotted line) until approximately $60 \%$ conversion. Thereafter, the experimental data showed a faster conversion than suggested by either model. This indicates that some simplifications made in the shrinking core model, such as spherical particles (Figure 3) and very narrow particle distributions (inlet Figure 8), cannot be applied [30].

$$
\begin{gathered}
\frac{t}{\tau}=1-3(1-X)^{\frac{2}{3}}+2(1-X) \\
\frac{t}{\tau}=1-(1-X)^{\frac{1}{3}}
\end{gathered}
$$

The particle size distribution measurement showed that the $\mathrm{Al}_{4} \mathrm{C}_{3}$ powder consisted of $10 \%$ particles smaller than $1.16 \mu \mathrm{m}$ up to $10 \%$ particles larger than $43.42 \mu \mathrm{m}$, leading to different diffusion pathway lengths during the reaction.

The kinetic modelling, either ash diffusion- or reaction-controlled, was not able to accurately describe the experimental data at $80^{\circ} \mathrm{C}$. As Razavi-Tousi and Szpunar [31] conclude in their study about a modified shrinking core model for the reaction of activated Al particles with hot water, several simplifications made by the model are not applicable. This seems to be the case for the presented reaction as well. The first deviation regarding the shape of the particles can be seen in Figure 3, proving the assumption of spherical particles wrong. Furthermore, the particle size also shows great variation (inlet Figure 8). The diffusion coefficient is also very unlikely to remain constant during the reaction, which can be assumed by the cracks in the treated particles as seen in Figure 3, which are probably formed as a result of gas production during the reaction. As the reaction also leads to formation of an $\mathrm{Al}(\mathrm{OH})_{3}$ shell, growing of particles due to stochiometric and density differences can be expected to happen as well [28]. An additional factor is the solubility of methane in water [32], which also leads to changes in the kinetic curves.

Summarizing, the following results were obtained:

- The conversion time of $100 \mathrm{mg} \mathrm{Al}_{4} \mathrm{C}_{3}$ to $\mathrm{CH}_{4}$ with only $\mathrm{H}_{2} \mathrm{O}$ can be accelerated from $240 \mathrm{~min}$ to $160 \mathrm{~min}$ by elevating the temperature from 60 to $80{ }^{\circ} \mathrm{C}$.

- The maximum recovery of $90-91 \%(w / w)$ appears to be independent from temperature in the area from 60 to $80{ }^{\circ} \mathrm{C}$ and can be considered complete.

- The proposed device can repeatably quantify $\mathrm{Al}_{4} \mathrm{C}_{3}$ in the range of $100 \mathrm{mg}$ (standard deviation of triplicates $<1 \%$ ).

- The particles are not dissolved during the treatment, but surface changes occur due to conversion to $\mathrm{Al}(\mathrm{OH})_{3}$ and $\mathrm{AlO}(\mathrm{OH})$.

- A shrinking core approach controlled by either reaction or ash diffusion cannot accurately describe the experimental data.

\section{Conclusions}

In this study, an autoclave device was coupled with NDIR process analytics to provide a solution for quantifying $\mathrm{Al}_{4} \mathrm{C}_{3}$ without the use of hazardous chemicals in industrial environments.

Experiments with pure $\mathrm{Al}_{4} \mathrm{C}_{3}$ showing the complete conversion to mainly $\mathrm{Al}(\mathrm{OH})_{3}$ with a smaller $\mathrm{AlO}(\mathrm{OH})$ fraction were successfully conducted. This was additionally checked by XRD, SEM, and TGA-IR.

The recovery, reproducibility, and precision of the device were successfully quantified and deemed appropriate for the intended use as a quality control tool for bigger sample sizes.

After the creation of a standard operating procedure, method validation at different concentrations of analyte must be carried out. This provides access to additional important 
parameters, such as limit of detection, limit of quantification, linearity, working range, and sensitivity.

Kinetic curves were recorded, and a basic modelling approach was proposed. However, neither basic reaction-controlled nor ash diffusion-controlled modelling led to sufficient agreement. Therefore, kinetic modelling requires closer examination of several parameters, such as particle shape and size, as well as SEM cross section analysis of partially converted particles to estimate the geometric aspects of conversion and the formation of cracks influencing the diffusion coefficient. Another approach might be to conduct experiments at $\mathrm{pH}$ values below 2 or above 11 where, as stated by Razavi-Tousi and Spunar [28] the $\mathrm{Al}(\mathrm{OH})_{3}$ layer becomes soluble in order to obtain information on kinetic values without the effects of diffusion. Diffusion could then be considered in additional experiments.

Possibilities for further improvement of analysis time were shown. Separating the reaction from the analyzing step utilizes the potential of the autoclave system, enabling reaction temperatures above $100{ }^{\circ} \mathrm{C}$. The analyzing step could be conducted after a cooling phase.

The main intended applications can be seen as bulk materials containing $\mathrm{Al}_{4} \mathrm{C}_{3}$ where analyte concentrations are in the $\mathrm{mg}$ area and bigger sample sizes are beneficial due to inhomogeneity. As industrial ambient conditions are mostly rougher, cheaper and more robust equipment that is easier to handle is preferred. In cases of processes causing $\mathrm{Al}_{4} \mathrm{C}_{3}$ formation, controlling the quantity of $\mathrm{Al}_{4} \mathrm{C}_{3}$ might lead to optimization of production parameters. This leads to less structural damage caused by hydrolyzation. In the case of $\mathrm{Al}_{4} \mathrm{C}_{3}$ being used as raw material, the quantification of $\mathrm{Al}_{4} \mathrm{C}_{3}$ enables the exact dosing of needed $\mathrm{Al}_{4} \mathrm{C}_{3}$ to prevent problems caused by unreacted $\mathrm{Al}_{4} \mathrm{C}_{3}$.

Therefore, the device intends to be an extension to the already existing GC and GC-MS methods, combining conversion and gas analytical measurement in one device.

Supplementary Materials: The following supporting information can be downloaded at: https: / / www.mdpi.com/article/10.3390/analytica3010008/s1. All data used for graphs is available as XLSX table.

Author Contributions: Conceptualization: S.N. and M.E.; methodology: S.N. and M.E.; investigation: S.N.; data curation: S.N.; formal analysis: S.N.; writing—original draft preparation: S.N.; writingreview and editing: M.E.; visualization: S.N.; funding acquisition: M.E. All authors have read and agreed to the published version of the manuscript.

Funding: This research was funded by RHI Magnesita.

Data Availability Statement: All data used for graphs are contained in Supplementary Materials (attached XLSX file).

Acknowledgments: Special thanks to Christian Weiss, Friedrich Kittinger, Kristina Stocker, Sandro Pesendorfer, and Thomas Braunsperger for the many helpful discussions over the course of writing this paper.

Conflicts of Interest: The authors declare no conflict of interest.

\section{References}

1. Khan, I.H. The effect of thermal exposure on the mechanical properties of aluminum-graphite composites. Metall. Trans. A 1976, 7, 1281-1289. [CrossRef]

2. Yang, M.; Scott, V.D. Carbide formation in a carbon fibre reinforced aluminium composite. Carbon 1991, 29, 877-879. [CrossRef]

3. Poirier, D.; Gauvin, R.; Drew, R.A.L. Structural characterization of a mechanically milled carbon nanotube/aluminum mixture. Compos. Part A Appl. Sci. Manuf. 2009, 40, 1482-1489. [CrossRef]

4. Okura, A.; Motoki, K. Rate of formation of intermetallic compounds in aluminium matrix-carbon fibre composites. Compos. Sci. Technol. 1985, 24, 243-252. [CrossRef]

5. Park, J.K.; Lucas, J.P. Moisture effect on SiCp/6061 Al MMC: Dissolution of interfacial Al4C3. Scr. Mater. 1997, 37, 511-516. [CrossRef]

6. Kothari, M.; Hung, W.N.P. Suppressing Aluminum Carbide in Welding Aluminum Silicon Carbide Composite. IJEMM 2018, 3 , 41-54. [CrossRef] 
7. Rodríguez-Reyes, M.; Pech-Canul, M.I.; Parga-Torres, J.R.; Acevedo-Dávila, J.L.; Sánchez-Araiza, M.; Lopez, H.F. Development of aluminum hydroxides in $\mathrm{Al}-\mathrm{Mg}-\mathrm{Si} / \mathrm{SiCp}$ in infiltrated composites exposed to moist air. Ceram. Int. 2011, 37, $2719-2722$. [CrossRef]

8. Kim, S.-M.; Koo, S.-M. Electrical properties of Al/Al 4 C 3 /4H-SiC diodes. Mater. Sci. Semicond. Process. 2018, 74, 170-174. [CrossRef]

9. Sun, Y.; Cui, H.; Gong, L.; Chen, J.; She, J.; Ma, Y.; Shen, P.; Wang, C. Carbon-in-Al4C3 nanowire superstructures for field emitters. ACS Nano 2011, 5, 932-941. [CrossRef]

10. Besterci, M. Preparation, microstructure and properties of Al-Al4C3 system produced by mechanical alloying. Mater. Des. 2006, 27, 416-421. [CrossRef]

11. Lu, Y.; Wang, X.; Zhang, Y.; Wang, J.; Kim, M.J.; Zhang, H. Aluminum Carbide hydrolysis induced degradation of thermal conductivity and tensile strength in diamond/aluminum composite. J. Compos. Mater. 2018, 52, 2709-2717. [CrossRef]

12. Nýblová, D.; Billik, P.; Noga, J.; Šimon, E.; Bystrický, R.; Čaplovičová, M.; Nosko, M. Degradation of Al4C3 Due to Atmospheric Humidity. JOM 2018, 70, 2378-2384. [CrossRef]

13. Atzenhofer, C.; Harmuth, H. Phase formation in $\mathrm{MgO}-\mathrm{C}$ refractories with different antioxidants. J. Eur. Ceram. Soc. 2021, 41, 7330-7338. [CrossRef]

14. Vidal-Sétif, M.H.; Lancin, M.; Marhic, C.; Valle, R.; Raviart, J.-L.; Daux, J.-C.; Rabinovitch, M. On the role of brittle interfacial phases on the mechanical properties of carbon fibre reinforced Al-based matrix composites. Mater. Sci. Eng. A 1999, 272, 321-333. [CrossRef]

15. Lee, J.-C.; Byun, J.-Y.; Park, S.-B.; Lee, H.-I. Prediction of Si contents to suppress the formation of Al4C3 in the SiCp/ $\mathrm{Al}$ composite. Acta Mater. 1998, 46, 1771-1780. [CrossRef]

16. Uthayakumar, H.; Radhakrishnan, P.; Shanmugam, K.; Kushwaha, O.S. Growth of MWCNTs from Azadirachta indica oil for optimization of chromium(VI) removal efficiency using machine learning approach. Environ. Sci. Pollut. Res. Int. 2022. [CrossRef]

17. Gokce, A.S.; Gurcan, C.; Ozgen, S.; Aydin, S. The effect of antioxidants on the oxidation behaviour of magnesia-carbon refractory bricks. Ceram. Int. 2008, 34, 323-330. [CrossRef]

18. Yan, L.; Tan, Z.; Ji, G.; Li, Z.; Fan, G.; Schryvers, D.; Shan, A.; Zhang, D. A quantitative method to characterize the Al 4 C 3 -formed interfacial reaction: The case study of MWCNT/Al composites. Mater. Charact. 2016, 112, 213-218. [CrossRef]

19. Wang, Y.-W.; Hao, P.-C.; Peng, J.-P.; Di, Y.-Z. Mechanism of Aluminum Carbide formation in aluminum electrolysis cells. J. Min. Metall. Sect. B Metall. 2020, 56, 321-326. [CrossRef]

20. Simensen, C.J. Gas-chromatographic analysis of carbides in aluminium and magnesium. Z. Anal. Chem. 1978, $292,207-212$. [CrossRef]

21. Edtmaier, C.; Segl, J.; Rosenberg, E.; Liedl, G.; Pospichal, R.; Steiger-Thirsfeld, A. Microstructural characterization and quantitative analysis of the interfacial carbides in $\mathrm{Al}(\mathrm{Si}) /$ diamond composites. J. Mater. Sci. 2018, 53, 15514-15529. [CrossRef]

22. Walvekar, A.P.; Sankar Das, M. Gas Chromatographic Determination of Carbide Carbon in Aluminium Nitride. Indian J. Chem. 1986, 25A, 755-757.

23. Sorg, D. Measuring Livestock CH4 Emissions with the Laser Methane Detector: A Review. Methane 2022, 1, 38-57. [CrossRef]

24. Zimmerle, D.; Vaughn, T.; Bell, C.; Bennett, K.; Deshmukh, P.; Thoma, E. Detection Limits of Optical Gas Imaging for Natural Gas Leak Detection in Realistic Controlled Conditions. Environ. Sci. Technol. 2020, 54, 11506-11514. [CrossRef] [PubMed]

25. Sun, S.; Ma, L.; Li, Z. Methane Emission Estimation of Oil and Gas Sector: A Review of Measurement Technologies, Data Analysis Methods and Uncertainty Estimation. Sustainability 2021, 13, 13895. [CrossRef]

26. Zefferer, M. Entwicklung eines Messverfahrens zur Bestimmung von Antioxidantien in Recyclingmaterial. Doctoral Dissertation, Montanuniversität Leoben, Leoben, Austria, 2014.

27. Janz, D. Optimierung eines Messverfahrens zur Bestimmung von Antioxidantien in Recyclingmaterial. Bachelor's Thesis, Montanuniversität Leoben, Leoben, Austria, 2017.

28. Razavi-Tousi, S.S.; Szpunar, J.A. Mechanism of Corrosion of Activated Aluminum Particles by Hot Water. Electrochim. Acta 2014, 127, 95-105. [CrossRef]

29. Koga, N.; Yamada, S. Controlled rate thermal decomposition of synthetic bayerite under vacuum. Solid State Ion. 2004, 172, 253-256. [CrossRef]

30. Levenspiel, O. The Chemical Reactor Omnibook, 5th ed.; OSU Book Stores Inc.: Corvallis, OR, USA, 1993; p. 51.2.

31. Razavi-Tousi, S.S.; Szpunar, J.A. Modification of the shrinking core model for hydrogen generation by reaction of aluminum particles with water. Int. J. Hydrogen Energy 2016, 41, 87-93. [CrossRef]

32. Duan, Z.; Mao, S. A thermodynamic model for calculating methane solubility, density and gas phase composition of methanebearing aqueous fluids from 273 to $523 \mathrm{~K}$ and from 1 to 2000bar. Geochim. Cosmochim. Acta 2006, 70, 3369-3386. [CrossRef] 